\title{
Government policy in developing social capital of small industry in facing ASEAN Economy Community era
}

\author{
Herrukmi Septa Rinawati
}

\author{
Universitas Bhayangkara \\ Jl., Ahmad Yani 114, Surabaya, Jawa Timur 60231, Republic of Indonesia
}

\begin{abstract}
This study aimed to know the obstacles and the government policy in developing the social capital of small industry in facing competition in ASEAN Economy Community (AEC) period. Using quantitative and qualitative as the methodology, this study obtained the data through interview and focus group discussion. The result showed that the development of social capital that not maximum enough was becoming the obstacle for small industry. The connection between the businessman association with other party, such as big industry, civil society organization, banking and other stake holders should be expanded. Meanwhile the government had done some policy in developing the social capital of small industry by holding a training and competition, increasing the access and relation of small industry with foreign and national company, also helping on the social capital. Therefore, small industry still can survive in facing the AEC era.
\end{abstract}

Keywords: ASEAN Economy Communit; social capital; small industry; government policy

\section{Introduction}

There was a change in economic structure in the last of twentieth century and the early of twenty-first century. The first was the market expand and crossed the country to the level between individuals due to information technology that allowed the contact became easier. The second was producer had access in marketing by minimalize the selling price because of the dismissal of the admission charge or import duty. It cannot be separated with the amount of agreement between governments in a certain region, such as ASEAN Economy Community (AEC). The third was the changing of the capital ownership mastery that crossed the countries barrier. It meant that within the multinational corporation (MNC), the capital ownership of foreign country established a factory with natural resources and human resources around, and made it into market. The fourth was the product did not appear in the form of goods and stock, and also currency. Thus, as a result, the currency exchange rate was very susceptible and depend on the demand and supply. This susceptibility had effect on the basic material and the product selling price. 
However, Indonesia had strategy in overcoming these condition. Nowadays, the association of regional businessman and merchant, especially in small industry, were developed under the license of Industrial Ministry, Cooperative and UMKM (Micro, Small, and Medium Enterprises), and other related institutions. This association was useful for the members in information distribution on the management of business, production technology, and marketing, especially in facing the competition in AEC era. Indonesia must increase the competitiveness of industrial products and services, and also develop the industry which based on value-added. Therefore, it was needed a hard work to do the product downstream policy by processing the primary production result. The implementation of African Continental Free Trade Area (ACFTA) and AEC had impact on reducing the cost of export and import for $0-5 \%$, also the deletion of quantitative restriction and other non-tariff barriers.

The opening of free trading spaces in ASEAN region was predicted to be able to push Indonesian economy development in positive way. The first was pushing the national income through export and import. The second was opening an opportunity of new industrialization in Indonesia region that had been retarded due to monetary crisis in 1998. The third was expanding the professional job opportunity for new young generation and giving a career opportunity in various region in ASEAN. However, at the same time, the market economy became a frightening specter for Indonesian entrepreneurs in the middle of the weak competitiveness of local industry, the weakness of national protection toward local industries was afraid to decrease the potential of local businessman and some small medium enterprise (UKM Bank) that still lack of economy aspects. AEC as an opportunity yet challenge for Indonesia, had purpose to increase the economic stabilization in ASEAN region. Some sectors that became Indonesia's leading in AEC 2015 were natural resources, information technology, and economy creative. These three sectors were stronger in Indonesia than the other ASEAN countries.

Since the acknowledgment of batik as one of the Indonesian cultural heritage by UNESCO on October, $2^{\text {nd }} 2009$. Batik which identic as a costume for special occasion was started to shift into a high valued fashion product that increase the demand of batik in market. Almost all Indonesian regions, including East Java, produced batik. In other side, started from 2012, Indonesia imported batik cloth and batik product from China with total price for 30 million US dollar or 285 million rupiah. It was an irony since batik was identic with Indonesian product. Moreover, according to the leader of Indonesian Textile Association (API - Asosiasi Pertekstilan Indonesia), Ade Sudrajat, the invasion on textile product, especially batik from China, had been occurred since the last 4 years. Based on the data of Central Bureau of Statistic (BPS), there were 1.037 ton of batik imported from China. These imported batik were categorized as a cheap batik which popular in lower middle class society.

Besides batik cloth, other China products that invaded local market in Indonesia were jacket, blazer, pants, woman and man clothes, handkerchief, scarf, and tie. This caused the domestic textile production became worse due to Indonesian market displacement by imported goods. Until the last of February 2013 the composition of imported clothes had reach $60 \%$ from the whole stock which marketed in Tanah Abang, Jakarta. The big amount of imported clothes from China was in- 
separable from ASEAN-China Free Trade Agreement 2010 in which the custom duty for import product could be decreased significantly. Therefore, in the era of AEC, social capital was very needed by the middle class industry in facing the invasion of goods and services from ASEAN countries. Hence, this study aimed to know the obstacles and the government policy of small industry social capital in facing AEC era.

\section{Literature review}

\section{Small industry}

The regulation of the Minister of Industry No. 64/M-IND/PER/2016 concerning on the total amount of labor and infestation for industrial business classification mentioned that small industry is an industrial activity which at most employ 19 labors and has infestation for less than 1 million rupiah, excluding the business land and building (Article 3, Paragraph 1). The business land and building as written on Paragraph 1 is a land and building which the location becomes one with the owner's place. According to Central Agency of Statistic (BPS - Badan Pusat Statistik), the definition of small industry is a business unit of industrial processes sector with the total of worker around 5-19 people. Sutojo and Ahmad (1994) stated that the general characteristic of small industry were consisted of: a) the activity tend to be informal and rarely have a business plan; b) the organization structure is simple; c) the worker is limited on the loose labor division; d) most of the small industry did not separate between private property and business property; e) bad accounting system, even has no accounting system; f) small economy scale which difficult in pressing the cost; g) marketing ability and market diversification is limited; h) thin profit margin.

The delayed growth of small industry in developed countries was occurred by the farmer's inability in recruiting workers (Tambunan, 2009). Meanwhile, the growth of labor was keep on growing along with the growth of the population, but not followed by the expansion of the agriculture land and the efficiency of agriculture economy due to food technology development. The other non-recruited labors were making urbanization to city and developing non-formal sector. Meanwhile, for those who stay were developing the non-farm sector, such as small industry for household. The main development fund was come from owner's private saving, loan from relatives, or from seller as delayed payment and down payment from customers.

\section{Social capital}

The concept of social capital was developed since 1950 with early application and get notice from experts in the last twenty year this year. Grootaert (2002) defined the social capital as an institution, a relationship, an attitude and a value which organize interaction among people and contribute to economic and social development. In wider definition, social capital was classified in two elements. The first element was structural social capital which relatively easy to be observed in objective way, such as network, association, institution, regulation and institutionalized procedure. While the second element was cognitive social capital which more subjective and hard to measured, such as attitude, behavior, value, interrelationship and trust. 
These two elements also differed based on the observation scope of micro, meso or macro level. In micro level the form of social capital was horizontal network from individual and family and the value which underlie the network. While in meso level the form was both horizontal and vertical network between groups, and between individual and group, such as local association. The widest scope was in macro level. The form of social capital in this level was institutional and political environment that covered all social and economic activities. These three levels of social capital could be seen below.

\begin{tabular}{|c|c|}
\hline \multicolumn{2}{|c|}{ Macro } \\
\hline State Institution Rule of Law & Governance \\
\hline Local Institution, Working Network & Trust, Local Norm, and Value \\
\hline
\end{tabular}

Figure 1. The social capital form and scope (Grootaert, 2002)

Bourdieu (1986) defined social capital as a group of potential or actual sources that connected to network ownership that could last for long from more institutional relation of mutual acquaintance or knowledge. It was social obligation (connection) that could be exchanged in a certain condition to the economic capital and could be institutionalized as a title within the society. Along with Wacquant, Bourdieu (1992) revised the definition of social capital as the total of actual or virtual sources grew within the individual or group with the kindness of a network that could last for long from more or less institutional relation of mutual acquaintance or knowledge. Meanwhile Coleman (1990) defined social capital based on its function. To him, social capital was not an entity but a kind of different entities. Putnam (1993) defined social capital as a characteristic of social organization, such as network, norms, and social trust, which facilitated the coordination and partnership for mutual benefit. Moreover, Fukuyama (1995) stated that social capital as people ability to cooperate in achieving goal within the group or organization which measured by the trust.

\section{ASEAN Economy Community (AEC)}

As a regional organization, ASEAN has recognized the importance of district integration. The ASEAN vision on 2020 was based on three pillar: economic, politic and social culture. As an effort to strengthen the ASEAN integration, in the $9^{\text {th }}$ of ASEAN Summit Conference in 2003 in Bali, ASEAN Community was established based on those three pillars, namely ASEAN Political Security Community, ASEAN Economic Community, and ASEAN Socio-Culture Community.

AEC was the form of ASEAN economic integration which establish the liberal trade system among ASEAN countries. The ASEAN Economy Community was officially released in the early year of 2016 with four pillar of AEC. The first pillar was ASEAN as a single market production based that supported by free flow of goods, service, infestation, educated labor, and free flow of modal. The second was ASEAN as a high competition sector with element of competition rules, consumer protection, right of intellectual property, infrastructure development, taxes, 
infrastructure, e-commerce. The third pillar was ASEAN as a sector with equal economy development along with the element of micro, meso, and macro business development, and ASEAN integration initiative with CMLV countries (Cambodia, Myanmar, Laos, and Vietnam) and the fourth was ASEAN as a fully integrated sector with global economy (ASEAN Secretariat, 2008).

In the $9^{\text {th }}$ ASEAN Summit Conference in 2003, 11 Priority Integration Sectors (PIS) was established. However in 2006, the PIS was developed into 12 which divided in two sections: 7 sectors of industrial good and 5 sectors of service. The 7 sectors of industrial good were consisted of agricultural based product, electronic, fishery, rubber based product, textile, automotive, and wood based product. While the 5 sectors of service were air transportation, e-ASEAN, health service, tourism, and logistic service.

In greeting the period of ASEAN liberal trade in $12^{\text {th }}$ sectors, Indonesia has been issued an important regulation of Act No. 7/2014 on trade which has been introduced to society as one of the strategy to block up the import product in Indonesia. It organized the general requirements on license for business agent who involved in trading activity in order to use Indonesian language in labeling and increasing the use of local product. Through this, government was required to control the availability of basic material for all Indonesian region, to define the barrier or prohibition of goods or services for national benefits to protect the national security.

\section{Methodology}

Research Methodology. This study used quantitative and qualitative methodology. Started with doing survey on some small industry craftsmen in Bojonegoro and Tulungagung. Then, using Forum Group Discussion (FGD) to deepen the research. Through these, the researcher developed the obtained data.

Data Collection. The data collection was done with survey and continued with interview with the Regional Stakeholder Organization of small industry development. The interviewees were coming from Department of Industry and Trade, Bappeda (Development Planning Agency at Sub-National Level), Agency for Community Empowerment, and small industry craftsmen who merged into small batik business center in Bojonegoro and Tulungagung.

Data Analyzing. The data were analyzed using descriptive and correlation statistic. Through the descriptive statistic, the capitals of culture were analyzed by connecting the government policy on strengthening micro small industry. However, the researcher was having a bit difficulty in getting the data on productivity and small industry marketing result.

\section{Result and Discussion}

\section{Obstacles}

Even though, the social capital of small industry was good enough which proved by the strong bonding between the craftsmen, but there were still some obstacles that interfere. The social capital of bridging and linking which connect the groups of businessman, such as big industry, civil society organization, banking, and other 
stakeholders, were not maximum yet. Thus, it needed to enhance the social capital of bridging and linking in order to develop the existing business through capital, marketing network expansion, business management enhancement and technical ability enhancement. Social capital with strong bonding within sociological system could create the feeling of sympathy, responsibility, reciprocity believe and acknowledgement of mutual believed cultural value. Tradition was an immortal behavioral norms which had strong integration with social behavior pattern. It had strong bonding with sanctions for the offender. Social bridging as an institution or mechanism was a social bonding that appeared as a reaction for various group characteristic. It was social lubricant that helped the development of capital social within a community and broader working space, either across the ethnical or private group. It also could be seen from public involvement as a citizenship, association, and network. Meanwhile, social linking as a social connection/network with relationship among some levels of social power or social status within the society.

\section{Government policy toward small industry}

This study showed that some of social capitals were not fully support the business. The social capital did not have a positive correlation with the sales turnover significantly. It was a compounding variable of politic, reciprocity and social solidarity participation, however only the politic participation (SCapPart) which had no significant correlation. Meanwhile, the social solidarity showed negative significant which meant the higher the social solidarity (SCapSS), the lower the turnover sales, and vice versa. Seeing on this result, then the social solidarity had role as bonding social capital. On the contrary, the reciprocity became supporter on social capital. The higher the reciprocity, the higher the profit. This could be seen in table below.

Table 1

Matrix correlation between sales turnover and social capital

\begin{tabular}{|c|c|c|c|c|c|}
\hline & & Sales Turnover & SCapPart & SCapRep & SCapSS \\
\hline & Pearson Correlation & 1 & ,077 &, $253^{\star \star}$ &,$- 280^{\star \star}$ \\
\hline \multirow[t]{3}{*}{ Sales Turnover } & Sig. (2-tailed) & &, 421 &, 008 & ,003 \\
\hline & $N$ & 110 & 110 & 110 & 110 \\
\hline & Pearson Correlation & 077 & 1 &,- 056 &, $664^{\star \star}$ \\
\hline \multirow[t]{3}{*}{ SCapPart } & Sig.(2-tailed) & ,421 & &, 563 &, 000 \\
\hline & $N$ & 110 & 110 & 110 & 110 \\
\hline & Pearson Correlation &, $253^{\star \star}$ &,- 056 & 1 &,- 021 \\
\hline \multirow[t]{3}{*}{ SCapRep } & Sig.(2-tailed) & ,008 &, 563 & &, 827 \\
\hline & $\mathrm{N}$ & 110 & 110 & 110 & 110 \\
\hline & Pearson Correlation &,$- 280 * \star$ &, $664^{\star \star}$ &,- 021 & 1 \\
\hline \multirow[t]{2}{*}{ sCapsS } & Sig.(2-tailed) &, 003 &, 000 & ,827 & \\
\hline & $N$ & 110 & 110 & 110 & 110 \\
\hline
\end{tabular}

The data showed that the amount of organization was donated the turnover significantly. Through the ANOVA analysis and the average ratio, this study showed that for those who had membership on more than one organization had bigger turnover in average. In short, if a businessman wanted to success, then he must be involved in some organizations which linked to his business. Though, by looking on the ANOVA analysis in table below, the profit or the bigger turnover could be obtained if becoming member in 3 organization of profession. 
ANOVA analysis

Table 2

\begin{tabular}{lccccc}
\hline & Sum of squares & $\boldsymbol{d f}$ & Mean square & $\boldsymbol{F}$ & Sig. \\
\hline Between Groups & 3059620613107820,000 & 2 & 1529810306553910,000 & 16,935 &, 000 \\
Within Groups & 9665718023255810,000 & 107 & 90333813301456,200 & & \\
Total & 12725338636363600,000 & 109 & & & \\
\hline
\end{tabular}

Tukey honestly significant difference with dependent variable: turnover

Table 3

\begin{tabular}{ccccccc}
\hline $\begin{array}{c}\text { Groups } \\
\text { (I) }\end{array}$ & $\begin{array}{c}\text { Groups } \\
\text { (II) }\end{array}$ & $\begin{array}{c}\text { Mean difference } \\
\text { (I-J) }\end{array}$ & Sig. & Std. error & \multicolumn{2}{c}{ 95\% confidence interval } \\
\cline { 5 - 7 }, 0 & 2,0 & $8544573,643^{*}$ &, 002 & 2463521,537 & 2689354,57 & 14399792,72 \\
& 3,0 & $-11583333,333^{*}$ &, 030 & 4480421,937 & $-22232256,67$ & $-934409,99$ \\
2,0 &, 0 & $-8544573,643^{*}$ &, 002 & 2463521,537 & $-14399792,72$ & $-2689354,57$ \\
& 3,0 & $-20127906,977^{\star}$ &, 000 & 4013231,706 & $-29666427,54$ & $-10589386,41$ \\
3,0 &, 0 & $11583333,333^{*}$ &, 030 & 4480421,937 & 934409,99 & 22232256,67 \\
& 2,0 & $20127906,977^{*}$ &, 000 & 4013231,706 & 10589386,41 & 29666427,54 \\
\hline
\end{tabular}

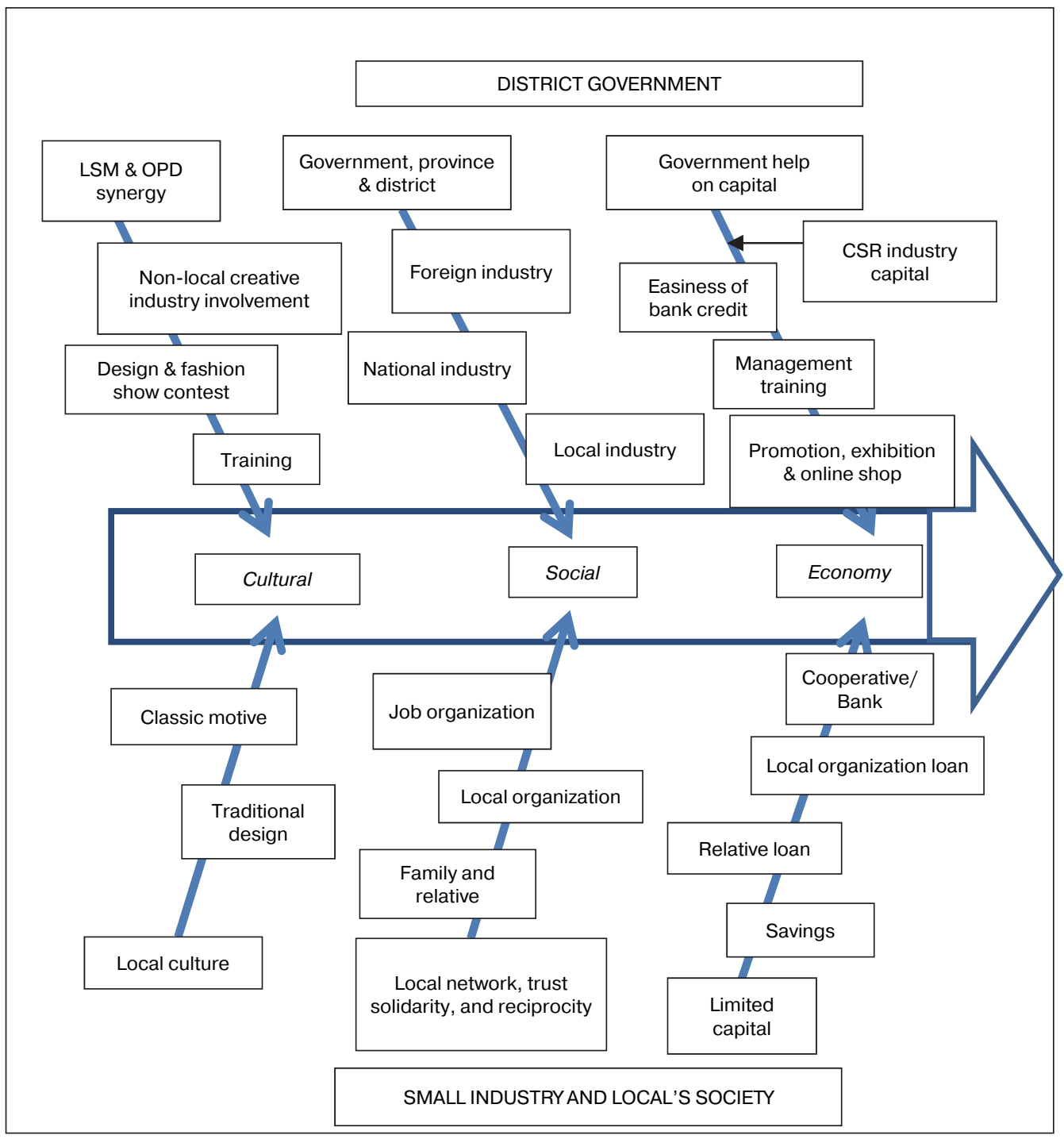

Figure 2. Government policy and local business 
With this statistical analysis, some actions could be done in strengthen the social capital and emphasize the government role within. The first step was conducting a training on creativity, since batik and clothes were product with creativity. Business man should had ability to be creative or Regional Government developed the network that able to support batik and clothes creation. It could be done by digging up the local wisdom.

The second step was capital strengthening. A batik businessman was always had trouble in capital. The network development on baking world and support from Non-Batik Company within the framework of Cooperate Social Responsibility (CSR) became the important support. However, the businessman should understood the management risk on the decision they took. The third step was management strengthening for craftsmen or businessman. Within the strengthening, the craftsmen or businessman obtained knowledge and ability of SWOT analysis related to AEC and other challengers. The ability in doing self-introspection of weakness and the ability in developing the strategy to face the competition in AEC era. Besides, businessman also needed to understand and do the management risk of what they have done. The fourth step was social capital transformation on social solidarity which not mere as a bonding among businessman but as a bride and link to the business. This awareness should exist in social network built by them. The solidarity itself had strengthen the relationship among them. They did not become a rival, but they helped in building the marketing relation. Thus it showed that most of the business used relatives networking as market place. The fifth step was the reciprocity or feedback as advantaged social capital or increasing the sales turnover. Thus the businessman could use those things in some aspects of production and marketing. The business specification on each businessman could be developed and completed each other so there was no competition among them. The differentiation of batik pattern could also strengthen the relation by exchanging customers. The customers could bought two different pattern from two sellers. The last step was strengthening and adding the network profession. Since the amount of organization could help the regional product marketing. The establishment of the association which supported by the District Government became the keyword in looking for the market.

\section{Conclusion}

Based on the result and discussion above, even though the social capital which owned by the small industry businessman was good enough, proved by the social bonding between the craftsmen, but there was still an obstacle. The obstacle was the social capital of bridging and linking, which connected the association of businessman with other parties, such as big industry, civil society organization, banking, and other stake holders, was not maximum yet. It needed to develop the existing business through the access enhancement on capital, expansion of marketing network, improvement on business management, and improvement on technical ability.

Furthermore, the development of social capital of small industry was inseparable from the other forms of social capital, those were cultural and economic capital that related to each other. There were three steps of government policy; the first was regional government through civil society organization and non-local small 
industry could be synergized in creating a training, design and fashion show competition, developing the classic pattern and traditional design based on local wisdom. The second was the social capital of bridging should be developed through the enhancement of connection and access from small industry businessman along with the government with foreign company and national or local company. This connection could enhance the access of small industry businessman on capital, ability and marketing. Meanwhile, within the organization of small industry (bonding), the intensity of social relationship must be increased. Such as solidarity, reciprocity, and trust within the organization itself, or the local and partnership organization. This was needed to create a safety atmosphere in improving the productivity. The third was the capital owned by small industry businessman was come from individual savings, loan from relatives, local organization, cooperative, and bank. The available capital enhancement could be done through government help or CSR help. Thus the economic capital could be increased if the capital along with the training and involvement in exhibition and market promotion were walked together.

\section{References}

Association of Southeast Asian Nation. (2008). ASEAN Economic Community Blueprint. Jakarta. ASEAN Secretariat.

Bourdieu P. (1986). The production of belief: contribution to an economy of symbolic goods. Media, Culture and Society, 2, 261-293.

Coleman J. (1990). Social capital and the common good. American Journal of Sociology, 94, S95-S120.

Departemen Perindustrian dan Perdagangan. (2002). IKM Buku i Kebijakan dan. Strategi Umum Pengembangan Industri Kecil menengah. Jakarta.

Fukuyama F. (1995). Trust: The Social Virtues and the Creation of Prosperity. Free Press. 100 p.

Grootaert C. (1998). Social Capital: The Missing Link? Social Capital Initiative Working Paper No. 3. The World Bank, Social Development Family, Environmentally and Socially Sustainable Development Network.

Putnam R.D. (1993). The masyarakat sejahtera: modal sosial dan kehidupan public. Amerika Prospect, 4(13), 35-42.

Sutojo S., Achmad H. (1994). Sumber Daya Manusia Berkualitas Mengubah Visi menjadi Realitas. Gramedia Pustaka Utama, Jakarta.

Tambunan T. (1999). Perkembangan Industri Skala kecil di Indonesia. Cetakan Pertama, PT. Mutiara Sumber Widya, Jakarta.

\section{Article history:}

Received: 08 April 2019

Revised: 12 May 2019

Accepted: 18 June 2019

\section{For citation:}

Rinawati H.S. (2019). Government policy in developing social capital of small industry in facing ASEAN Economy Community era. RUDN Journal of Economics, 27(2), 249-258. http://dx.doi.org/10.22363/2313-2329-2019-27-2-249-258 
Bio note:

Rinawati Herrukmi Septa - researcher, Universitas Bhayangkara Surabaya. E-mail: herruknisepta30@gmail.com

Научная статья

\title{
Государственная политика развития социального капитала малого бизнеса в странах АСЕАН
}

\author{
Х.С. Ринавати \\ Университет Бхаянгкара \\ Республика Индонезия, 60231, Джава Тимур, Сурабая, Ахмад Яни, 114
}

Исследование посвящено изучению политики правительства и препятствий в развитии социального капитала малых предприятий в условиях конкуренции в рамках Экономического сообщества АСЕАН. Данные были собраны путем интервью и обсуждения в фокус-группах, а также с помощью количественных и качественных методов. Результат показал, что развитие социального капитала, пока недостаточно развитого, становится препятствием для малой промышленности. Должна быть расширена связь между объединением предпринимателей (например, крупной промышленностью), с одной стороны, и организациями гражданского общества, банковским сектором и прочими заинтересованными сторонами, с другой. Между тем правительство провело определенную политику в развитие социального капитала малой промышленности, организуя тренинги и соревнования, увеличивая доступ и расширяя связи малой промышленности с иностранными и национальными компаниями, а также помогая развитию социального капитала. Таким образом, малая промышленность все еще может выжить в эпоху Экономического сообщества АСЕАН.

Ключевые слова: Экономическое сообщество АСЕАН; социальный капитал; малая промышленность; государственная политика

\section{История статьи:}

Дата поступления в редакцию: 08 апреля 2019

Дата проверки: 12 мая 2019

Дата принятия к печати: 18 июня 2019

\section{Для цитирования:}

Rinawati H.S. Government policy in developing social capital of small industry in facing ASEAN Economy Community era (Государственная политика развития социального капитала малого бизнеса в странах АСЕАН) // Вестник Российского университета дружбы народов. Серия: Экономика. 2019. Т. 27. № 2. С. 249-258. http://dx.doi.org/10.22363/ 2313-2329-2019-27-2-249-258

\section{Сведения об авторе:}

Ринавати Хирукми Септа - исследователь, Университет Бхаянгкара. E-mail: herruknisepta30@gmail.com 